\title{
Cooperate with REMS Audits
}

National Cancer Institute

\section{Source}

National Cancer Institute. Cooperate with REMS Audits. NCI Thesaurus. Code C128521.

The healthcare provider or setting must cooperate with audits of their activities conducted by the REMS program. 